\title{
Maternal and neonatal predictive variables for quality of cord blood as a source of stem cells
}

\author{
Tyseer Marzouk*1, Inas Mohamed Abd-Allah² \\ ${ }^{1}$ Department of Woman's Health and Midwifery Nursing, Faculty of Nursing, Mansoura University, Egypt \\ ${ }^{2}$ Department of Maternity, Obstetrics and Gynecology Nursing, Faculty of Nursing, Suez Canal University, Egypt
}

Received: May 13, 2018

DOI: $10.5430 /$ jnep.v8n11p102
Accepted: June 27, 2018

Online Published: July 9, 2018

\begin{abstract}
Objective: This study aimed to identify the maternal and neonatal predictive variables for quality of cord blood as a source of stem cells.

Methods: A descriptive design was followed in this study. A purposive sample of 143 pairs; pregnant women assigned for elective cesarean section and their newborns, was enrolled in current study. The subjects were recruited from the Operating Theater of Mansoura University Hospital, Egypt. One hundred forty three umbilical cord blood units were collected in utero from cesarean deliveries. The collected units were assessed for its blood volume and total nucleated cells content. An assessment sheet of 12 items was used as a tool of data collection.

Results: The greater blood volume and higher nucleated cells obtained from the primigravida, between 37 to 40 gestation weeks, and those not exposed to cigarette smoke during pregnancy $\left(163.1 \pm 24.8 \mathrm{ml}\right.$ and $10.2 \pm 2.8 \times 10^{6}$ cells $/ \mathrm{ml}, 169.3 \pm 22.6 \mathrm{ml}$ and $11.2 \pm 1.9 \times 10^{6}$ cells $/ \mathrm{ml}, 169.8 \pm 21.4 \mathrm{ml}$ and $10.0 \pm 2.9 \times 10^{6}$ cells $/ \mathrm{ml}$ respectively). The birth weight $\geq 3,600 \mathrm{~g}$, the first born baby, and the heavier placenta $(\geq 550 \mathrm{~g})$ produced significantly greater blood volume and cellular content $(161.5 \pm$ $20.6 \mathrm{ml}$ and $9.8 \pm 2.4 \times 10^{6} \mathrm{cells} / \mathrm{ml}, 164.6 \pm 19.4 \mathrm{ml}$ and $9.6 \pm 2.7 \mathrm{cells} / \mathrm{ml}, 164.8 \pm 19.6 \mathrm{ml}$ and $10.2 \pm 2.6 \times 10^{6} \mathrm{cells} / \mathrm{ml}$ respectively).

Conclusions: Primigravida, delivery between 37 to 40 gestation weeks, and no exposure to cigarette smoke during pregnancy were the maternal variables that were associated with larger blood volume and higher cellular content. Even though, first born baby, birth weight $\geq 3,600 \mathrm{~g}$, and placenta weight $\geq 550 \mathrm{~g}$ were the neonatal variables.
\end{abstract}

Key Words: Blood volume, Cellular content, Umbilical cord blood units, Predictive variables, In-utero collection, Stem-cell therapy

\section{INTRODUCTION}

The stem cell is a dominant cell that can form nearly any tissue in the human body. Peripheral blood, bone marrow, and umbilical cord blood (UCB), in that order of inclination are the main sources of stem cells. ${ }^{[1]}$ The diversity of UCBderived stem cells enables physicians to treat more than 70 life-threatening diseases. ${ }^{[2]}$ UCB-derived stem cells provide hope to patients with chronic incurable diseases. Using UCB stem cells, clinical trials hold a promise for curative rather than palliative therapy for type I diabetes mellitus patients. ${ }^{[3]}$

There has been a rapid surge in UCB transplantation associated with increased number of cord blood banks throughout the world. Private or autologous cord blood banks are

\footnotetext{
*Correspondence: Tyseer Marzouk; Email: tm_fathy@yahoo.com; Address: Department of Woman’s Health and Midwifery Nursing, Faculty of Nursing, Mansoura University, Egypt.
} 
available to the owners and/or their family, while public or allogenic cord blood banks are open to all recipients whose tissue group matches. ${ }^{[4]}$ It is important to state, that it was emphasized in a previous report of the European Commission "Ethical Aspects of Umbilical Cord Blood Banking", that it is right to support public cord blood banking for allogenic purposes. ${ }^{[4]}$ However, it is imperative to reminder that the donations are made voluntarily. ${ }^{[5,6]}$

Each individual has one chance in a lifetime to save one's own UCB. Accordingly, this requires nurses who are working at the delivery room to collect high-quality UCB units, consequently improving the chances of future lifesaving. ${ }^{[2]}$ Acceptance or rejection of UCB units for banking are influenced by the number of stem cells per unit, which is mirrored by the total nucleated cell (TNC) content in each one. ${ }^{[7]} \mathrm{Op}$ timizing donor selection could be an abundant target for the nursing staff and obstetricians working in delivery room; they are the main responsible personnel for collecting UCB units.

Earlier researches investigated the donor's criteria that are associated with larger blood volume and higher cellular content. It was reported that type of delivery, parity, birth weight, sex of newborn, weight of placenta, and method of collection are correlated with either one or both of the two UCB quality indicators: UCB volume and TNC content. ${ }^{[8,9]}$ However, previous findings that gave attention to the maternal and neonatal variables which might increase suitability of UCB units for banking are still open for discussion. ${ }^{[10]}$

\subsection{Significance of the study}

About $54.1 \%$ of the collected cord blood units are discarded before processing due to volume deficiency, laboratory issues or shipping obstacles. ${ }^{[7]}$ Research studies seeked for the factors affecting the blood volume and number of TNC obtained from the umbilical cord are inadequate in Egyptian population. Identifying these variables can result in reducing the cost and time spent in collecting, processing, and storing of unsuitable cord blood units. ${ }^{[10]}$ Thus, the present study was conducted to identify the maternal and neonatal predictive variables for quality of cord blood as a source of stem cells.

\subsection{Operational definitions}

\subsubsection{Umbilical cord blood unit}

Umbilical cord blood unit is a special bag containing the collected cord blood. Umbilical cord blood is the blood left over in the placenta and in the umbilical cord after childbirth. It contains red blood cells, white blood cells, plasma, platelets and is also rich in hematopoietic stem cells. The blood can be collected by piercing vein of the umbilical cord using a needle connected to the cord blood bag.

\subsubsection{Quality of the umbilical cord blood unit}

Quality of the umbilical cord blood unit can be judged by the blood content of the stem cells per unit. Number of stem cells per each umbilical cord blood unit is mirrored by its TNC content. ${ }^{[7]}$

\subsection{Aim of the study}

This study aimed to identify the maternal and neonatal predictive variables for quality of cord blood as a source of stem cells.

\subsection{Study question}

To accomplish the aim of this study, one question was voiced: "What are the maternal and neonatal variables that can predict the higher quality indicators of UCB units; cord blood volume and TNC content?"

\section{SUBJECTS AND METHOD}

\subsection{Research design}

A descriptive design was followed to achieve the aim of the prevailing study.

\subsection{Study setting}

This study was conducted at the Operating Theater of Mansoura University Hospital, Egypt. It was the site of collecting the UCB units in this study. The operating theatre of Mansoura University Hospital receives around 1,500 pregnant mothers referred for cesarean deliveries annually. The hematology laboratory at the Oncology Center of Mansoura University Hospital was a supportive setting; where the TNC content was identified for each UCB sample.

\subsection{Sampling}

A purposive sample of 143 women assigned for elective cesarean section and their neonates was enrolled in this study. The women were eligible to be enrolled in the current research if was 1) Free from any medical or obstetric problems, 2) Assigned for elective cesarean section without experiencing stressful events of the first stage of labor. Each newborn baby was eligible to be joined in this research if had: 1) Umbilical cord not adversely affected by any abnormality that interferes with the blood aspiration; such as thrombi, false or true knot, 2) Free from known congenital anomalies, and 3) Recorded a first minute APGAR score of 7-10 points.

\subsection{Sample size calculation}

The aim of the existing study was to identify the maternal and neonatal predictive variables for quality of cord blood as a source of stem cells. A previous study by Keersmaekers et al. (2014), had shown that the neonatal birth weight 
that met the TNC requirement was $3,503 \pm 463$ grams compared to 3,215 \pm 453 grams for those that did not met the TNC requirement. ${ }^{[7]}$ To calculate the sample size with precision/absolute error meet of 5\% and type 1 error of $5 \%$, the following formula was used: Sample size $=[2 \times(\mathrm{SD}$ obtained from a previous study $\left.)^{2} \times\left(\mathrm{Z}_{\alpha / 2}+\mathrm{Z}_{\beta}\right)^{2}\right] /$ mean difference obtained from previous study. ${ }^{[11]}$ Therefore, $\mathrm{n}=$ $\left[2 \times(463)^{2} \times(1.96+0.84)^{2}\right] /[3,503-3,215]=142.02$. Accordingly, the sample size required in this study was 143 women with their neonates.

\subsection{Tool of data collection}

One tool was used to collect the required data.

Tool I: Assessment sheet: The researcher used an assessment sheet of three parts in data collection. It enclosed basic characteristics of the pregnant women: in terms of maternal age, gravidity, gestation weeks and exposure to cigarette smoke during pregnancy. This section was completed from the medical records before delivery. Information on the newborn was included in the second part of the assessment sheet; particularly neonatal gender, birth weight, and order of birth. The last part of the assessment sheet included description of the placentae and the collected UCB units. Placentae were described by diameter, weight, and length of the umbilical cord, while the UCB units were assessed for its blood volume in ml, and TNC count. This sheet was completed by a researcher after childbirth. Content validity of the assessment sheet was proven by a panel of five experts in maternity nursing and obstetrics medicine.

\subsection{Ethical considerations}

The board of Obstetrics and Gynecology department of Mansoura University Hospital and Ethical Committee of Nursing Faculty approved the existing study conduction. Each participant woman was signed an informed written consent before childbirth. After assessment of the study outcome, the UCB units were endorsed to the Mansoura Research Center for Cord Stem Cells (MARC-CSC) staff members. The UCB units were used for research purposes only without any intend to donate it to any person before taking owner's permission.

\subsection{Pilot study}

A pilot study was done on $10 \%$ of the required sample (n $=14$ UCB units). Its aim was to investigate clarity of the developed tool and to identify the barriers that may impede the researchers in collecting the blood units. Result of the pilot indicated that the tool's statements were clear and no corrections were done. Pilot sample was excluded from the analyzed study sample.

104

\subsection{Field work}

\subsubsection{Preparation for the work}

Before collecting the UCB units, the researcher who was responsible about the UCB units collection received a training; under patronage of staff members of MARC-CSC, on how to collect the UCB units from the cesarean section field without interfering the operating staff practices. As well as, got approvals for carrying out the research from the concerned authorities. This phase started on January 2016 and consumed around eight weeks.

\subsubsection{Collection of UCB units}

Initially, each eligible woman was signed an informed written consent after clarifying the study nature. To collect the UCB units, the trained researcher attended the operating theatre two days weekly. Researcher's attendance was based on the operating theater schedule of elective Cesarean deliveries. All UCB units were collected in utero; before placental separation. In utero collection was done according to the following steps: 1) The researcher scrubbed before the operation start; with the operating theatre team. 2) At the moment of childbirth, the surgeon was requested to clamp the umbilical cord as near from the baby's side as possible. This action aims to preserve the longest available part of the cord toward placental site. Thus, get larger blood volume. 3) The umbilical cord was transected within 10 seconds from childbirth; according to the protocol of care in the operating theatre, Mansoura University Hospital. 4) Before placenta expulsion and within few seconds from taking the newborn baby out of the surgical field to the radiant warmer, the distal part of the umbilical cord from the placental site was cleaned by $70 \%$ alcohol and Povidone-iodine swab. 5) The umbilical cord vein was punctured by needle of a cord blood collection set and the UCB was allowed to drain until the vein was shrunken. The UCB collection set is a specific set for UCB collection. It contains $30 \mathrm{ml}$ anticoagulant (CPDA-1 U.S.P.). Total number of UCB units was collected in about six months; started from March to August 2016.

\subsubsection{Assessment of the UCB units}

Each UCB unit was taken after collection to be assessed for its volume and content of nucleated cells.

The UCB volume was determined in grams by using a weighing scale. Net volume of the harvested cord blood was calculated by deducting weight of the empty unit (42 g) and the anticoagulant volume $(30 \mathrm{ml})$ from the gotten weight. Supposing that $1 \mathrm{gm}$ equals $0.95 \mathrm{ml}$. The nucleated cell count was identified; by using an automatic cell counter (CELLDYN 3700, Abbott Laboratories, and Abbott Park, IL) at the hematology laboratory, per $1 \mathrm{~cm}$ blood taken from the collected UCB unit. The TNC count per UCB unit was cal- 
culated by multiplying the gotten number with the net blood volume. Thereafter, the collected data coded, analyzed, and correlated. This step took about two months; from September to October 2016.

\subsection{Strengths and weaknesses of the study}

Investigating of a new factor; the exposure to cigarette smoke during pregnancy, may strengthen the results of this study. On the other hand, collecting the UCB units from Cesarean births only and recruiting the healthy women and newborns may limit generalizing the present study findings. As, maternal and fetal compromise may influence the quantity and quality of cord blood stem cell.

\subsection{Data analysis}

All statistical analyses were performed using SPSS for windows version 20.0 (SPSS, Chicago, IL). Data were tested for normality of distribution prior to any calculations. Continuous data were normally distribute and were expressed in mean \pm standard deviation (SD). Categorical data were expressed in number and percentage. The comparisons were determined using Student's $t$ test or ANOVA test for variables with continuous data while chi-square test was used for comparison of variables with categorical data. Statistical significance was set at $p<.05$.

\section{RESULTS}

\subsection{Descriptive data of the participant women, new- borns, and placentae}

The descriptive data of the participant women are demonstrated in Table 1. Mothers' age ranged from 20 to 40 years with an average of $26.8 \pm 5.4$ years. Among these mothers, $42(29.4 \%)$ were primigravida while $101(70.6 \%)$ were multigravida. The average gestational age of the current pregnancy was $38.5 \pm 1.0$ weeks with $18(12.6 \%)$ of the women were between 37 weeks and 38 weeks, 108 (75.5\%) were more than 38 weeks to 40 weeks and $17(11.9 \%)$ were beyond 40 weeks. Table 1 also shows that $86 \%$ of the mothers were exposed to cigarette smoke.

The descriptive data of the participant newborns are shown in Table 2. Female gender represented 65 (45.5\%) of the newborns, while $78(54.5 \%)$ were males. The newborn average weight was 3,310.1 \pm 547.7 grams. Of these newborns, $51(35.7 \%)$ were the first born baby, while $92(64.3 \%)$ were the second or more.

Table 3 clarifies the descriptive data of the placentae. The placental weight ranged from $300 \mathrm{~g}$ to $600 \mathrm{~g}$ with an average of $462.2 \pm 75.8 \mathrm{~g}$. The placental diameter ranged from $20-24$ $\mathrm{cm}$ with an average of $21.8 \pm 1.5 \mathrm{~cm}$, while the umbilical cord length ranged from $54-59 \mathrm{~cm}$ with an average of 56.6 $\pm 1.6 \mathrm{~cm}$.

Table 1. Descriptive data of the participant women $(n=143)$

\begin{tabular}{lll}
\hline Characteristics & Mean \pm SD or n & $\%$ \\
\hline $\begin{array}{l}\text { Mother's age (years) } \\
\text { Mean } \pm \text { SD }\end{array}$ & $26.8 \pm 5.4$ & \\
Range & $20-40$ & \\
Gravidity (n, \%) & & \\
Primigravida & 42 & 29.4 \\
Multigravida & 101 & 70.6 \\
Gestation age (weeks) & & \\
$37-38$ & 18 & 12.6 \\
$>38-40$ & 108 & 75.5 \\
$>40$ & 17 & 11.9 \\
Mean \pm SD & $38.5 \pm 1.0$ & \\
Exposure to cigarette smoke & \\
Yes & 123 & 86 \\
No & 20 & 14 \\
\hline
\end{tabular}

Table 2. Descriptive data of the participant newborns $(\mathrm{n}=$ 143)

\begin{tabular}{lll}
\hline Characteristics & Mean \pm SD or n & \% \\
\hline $\begin{array}{l}\text { Newborn gender } \\
\text { Female }\end{array}$ & 65 & 45.5 \\
Male & 78 & 54.5 \\
Newborn weight (gm) & & \\
$2,400-<3,000$ & 53 & 37.1 \\
$3,000-<3,600$ & 38 & 26.6 \\
$3,600-4,200$ & 52 & 36.4 \\
Mean \pm SD & $3,310.1 \pm 547.7$ & \\
Range & $2,400-4,200$ & \\
Order of birth & & \\
First baby & 51 & 35.7 \\
Second or more baby & 92 & 64.3 \\
\hline
\end{tabular}

Table 3. Descriptive data of the placentae $(n=143)$

\begin{tabular}{lll}
\hline Characteristic & Mean \pm SD or $\mathbf{~}$ & \% \\
\hline Placental weight $(\mathbf{g m})$ & & 55.9 \\
$\quad<500$ & 80 & 21.7 \\
$500-<550$ & 31 & 22.4 \\
$\geq 550$ & 32 & \\
Mean \pm SD & $462.2 \pm 75.8$ & \\
Range & $300-600$ & \\
Placental diameter $\mathbf{( c m )}$ & \\
$\quad$ Mean \pm SD & $21.8 \pm 1.5$ \\
$\quad$ Range & $20-24 \mathrm{~cm}$ \\
Umbilical cord length $\mathbf{( c m )}$ & \\
Mean \pm SD & $56.6 \pm 1.6$ \\
Range & $54-59 \mathrm{~cm}$ \\
\hline
\end{tabular}




\subsection{The UCB volume and TNC content according to the} maternal characteristics

Table 4 shows that the UCB volume obtained from newborns of primigravidae was significantly greater than that obtained from those of multigravidae by a mean difference of 10.9 $\mathrm{ml}(t=2.85, p=.005)$. Similarly, the TNC obtained from those of primigravidae was significantly greater than that obtained from those of multigravidae by $1.9 \times 10^{6} \mathrm{cells} / \mathrm{ml}(t$ $=4.20, p<.001)$. Newborns of women exposed to cigarette smoke during pregnancy, provided significantly lower UCB volume and cellular content compared to those not exposed to cigarette smoke by mean differences of $16.7 \mathrm{ml}$ and $1.3 \times$ $10^{6} \mathrm{cells} / \mathrm{ml} ; p<.001$ and .036 respectively. The same table does not show significant difference between the mothers $<$ 30 years and those $\geq 30$ years of age regarding the obtained UCB volume nor the TNC content $(p=.259$ and .497 respectively). Figure 1 shows that the both UCB quality indicators; UCB volume and TNC content, were inversely correlated with the gestation age $(r=0.173, p=.039 \& r=0.186, p$ $=.026$ respectively). Equally, the UCB volume and TNC content were reduced by advanced gestation weeks beyond 40 weeks.

Table 4. The UCB volume and TNC content according to the maternal characteristics $(n=143)$

\begin{tabular}{lll}
\hline $\begin{array}{l}\text { Maternal } \\
\text { characteristics }\end{array}$ & $\begin{array}{l}\text { Blood volume } \\
(\mathbf{m l})\end{array}$ & $\begin{array}{l}\text { TNC count } \\
(\times \mathbf{1 0} / \mathbf{m l})\end{array}$ \\
\cline { 2 - 3 } Mean \pm SD & Mean \pm SD \\
\hline Maternal age (years) & & \\
$<30$ years & $154.3 \pm 21.3$ & $8.8 \pm 2.5$ \\
$\geq 30$ years & $159.2 \pm 22.0$ & $9.1 \pm 2.9$ \\
Mean difference & 4.9 & 0.3 \\
$t$ & 1.13 & 0.68 \\
$p$ & .259 & .497 \\
Gravidity number & & \\
Primigravida & $163.1 \pm 24.8$ & $10.2 \pm 2.8$ \\
Multigravida & $152.2 \pm 19.2$ & $8.3 \pm 2.3$ \\
Mean difference & 10.9 & 1.9 \\
$t$ & 2.85 & 4.20 \\
$p$ & $.005 *$ & $<.001 * *$ \\
Exposure to cigarette & smoke & \\
Yes & $153.1 \pm 20.7$ & $8.7 \pm 2.5$ \\
No & $169.8 \pm 21.4$ & $10.0 \pm 2.9$ \\
Mean difference & 16.7 & 1.3 \\
$t$ & 3.33 & 2.12 \\
$p$ & $<.001 * *$ & $.036 *$ \\
\hline$* p<.05 ; * *<.01$ & &
\end{tabular}

3.3 The UCB volume and TNC content according to the newborns and placental characteristics

Table 5 clarifies that there was no significant difference between the male and female genders in the produced amount of UCB nor TNC content ( $p=.647$ and .193 respectively). The harvested blood volume and TNC count were significantly affected by the order of birth; in favor to the first order of birth. As, amount of the collected UCB and TNC content given by the first baby were higher than that obtained from the second or more babies by mean differences of $14.3 \mathrm{ml}$ and $1.1 \times 10^{6}$ cells $/ \mathrm{ml}$ respectively; $p<.001$ and .013 respectively.

It is obvious from Figure 2 that the blood volume obtained from the umbilical cord was positively correlated with the newborn weight $(r=0.280, p<.001$, Figure $2 a)$. Similarly, the TNC content obtained from the umbilical cord was positively correlated with the newborn weight $(r=.256, p<.001$, Figure $2 b$ ). As, the higher birth weight; $\geq 3,600$ g, yielded significantly greater blood volume and higher cellular count. As shown in Figure 3 the heavier placentae ( $\geq 550 \mathrm{~g}$ ) gave significantly greater UCB volume and higher cellular count $\left(164.8 \pm 19.6 \mathrm{ml}\right.$ and $10.2 \pm 2.6 \times 10^{6} \mathrm{cells} / \mathrm{ml} ; p=.013$ and .003 respectively) compared to those $<550 \mathrm{~g}$.

\section{Discussion}

The present study aimed to identify the maternal and neonatal predictive variables for quality of cord blood as a source of stem cells. This aim was attained through the present study findings. The findings revealed the maternal variables that might predict the production of the UCB volume and the TNC count, as primigravida, childbirth between 37 to 40 weeks gestation, and the non-exposure to cigarette smoke during pregnancy. Even though, neonatal variables were the first born; whatever male or female, the larger birth weight $\geq$ $3,600 \mathrm{~g}$, and those had heavier placenta $\geq 550 \mathrm{~g}$. Thus, the study question "What are the maternal and neonatal variables that can predict the higher quality indicators of UCB units; cord blood volume and TNC content?" was answered.

On comparing amount of the obtained cord blood and total nucleated cell count according to the mothers' age, the present study findings revealed that there were no significant differences between the UCB volume and TNC content produced by the pregnant mothers $<30$ years and those at or elder than 30 years of age. This finding is consistent with that of a Chinese study involved 10 in utero collected cord blood samples from elective Caesarean section. ${ }^{[6]}$ Yet, the same finding is inconsistent with that of Wen; ${ }^{[12]}$ found significant association between the mother's age and UCB volume and cellular content in an analysis of 1,549 UCB units of Taiwanian women. The difference between the present study finding and that of Wen, can be related to the difference of mean age of the subjects of the two studies. 


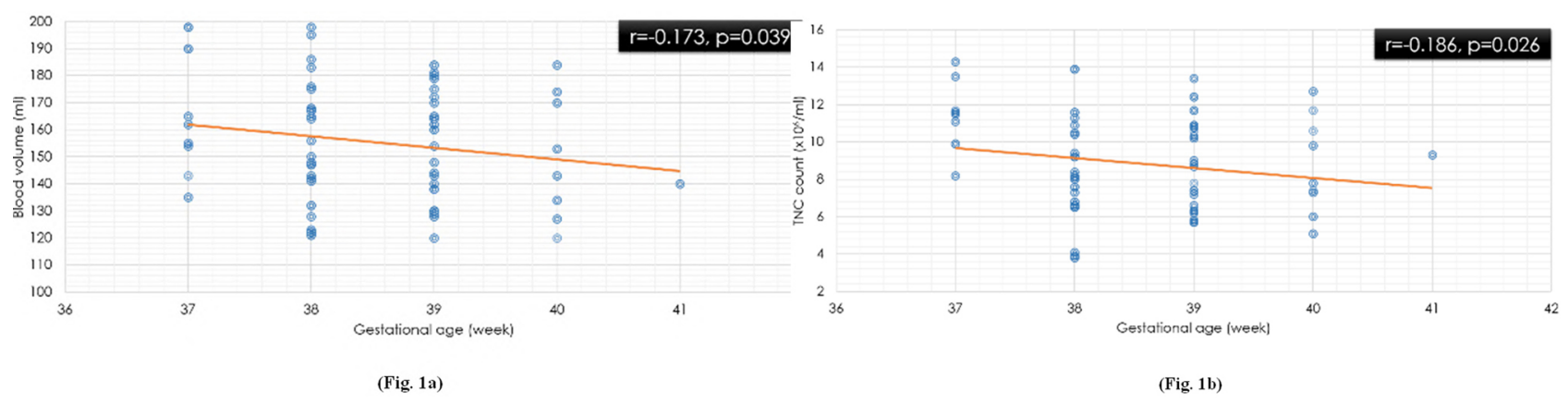

Figure 1. Correlation between the gestational age and (a) blood volume and (b) TNC

Table 5. The UCB volume and TNC content according to the newborn characteristics $(n=143)$

\begin{tabular}{lll}
\hline $\begin{array}{l}\text { Neonatal } \\
\text { characteristics }\end{array}$ & $\begin{array}{l}\text { Blood volume } \\
(\mathbf{m l})\end{array}$ & $\begin{array}{l}\text { TNC count } \\
(\times \mathbf{1 0} / \mathbf{m l})\end{array}$ \\
\cline { 2 - 3 } & Mean \pm SD & Mean \pm SD \\
\hline $\begin{array}{l}\text { Newborn gender } \\
\text { Female }\end{array}$ & $154.5 \pm 23.3$ & $9.2 \pm 2.6$ \\
Male & $156.2 \pm 20.0$ & $8.6 \pm 2.7$ \\
Mean difference & 1.7 & 0.6 \\
$t$ & 0.46 & 1.31 \\
$p$ & .647 & .193 \\
Order of birth & & \\
First baby & $164.6 \pm 19.4$ & $9.6 \pm 2.7$ \\
Second or more baby & $150.3 \pm 21.0$ & $8.5 \pm 2.5$ \\
Mean difference & 14.3 & 1.1 \\
$t$ & 3.99 & 2.52 \\
$p$ & $<.001^{* *}$ & $.013^{*}$ \\
\hline${ }^{*} p<.05 ; * * p .01$ & &
\end{tabular}

The present study finding revealed a significant difference in the UCB volume and the TNC content produced by the primigravida and the multigravida; in favor to the primigravida women. Conversely, Keersmaekers et al., ${ }^{[7]}$ found no significant power of the gravidity number on the obtained UCB volume and its cellular content in a study included 7,839 in utero collected UCB units at Michigan. This disagreement between the present study finding and that of Keersmaekers and colleagues could be related to the discrepancy between the subjects criteria. Keersmaekers' study included both low and high risk pregnancy and both vaginal and Cesarean deliveries, while the present study excluded high risk pregnancy and was limited to Cesarean birth only.

The current study demonstrated that the gestational age was inversely correlated with the collected blood volume and its cellular content. In other words, with advanced gestation beyond 40 weeks there were lower nucleated cell count and lesser blood volume. Parallel, Wen and coauthors ${ }^{[12]}$ found gestation age beyond 40 weeks inversely influenced the UCB volume. This finding may be explained by the fact that with advancing gestation there is a physiological placental senescence causing a reduction in fetal oxygen supply and producing vasoconstrictors. Such changes result in decreased blood volume at birth. Yet, other studies ${ }^{[13,14]}$ showed a positive correlation between the gestation age and cellular content and attributed such increase of cellular content to the fetal defense mechanisms against hypoxia episodes associated with advanced gestation age and placental aging. Meanwhile, Abdelrazek and colleagues found no correlations between the gestational age and the both studied UCB quality indicators in a study involved UCB units of 200 Egyptian women. ${ }^{[15]}$ Abdelrazek and colleagues attributed the given finding to selection of a narrow range of gestation age; from 35 to 40 weeks.
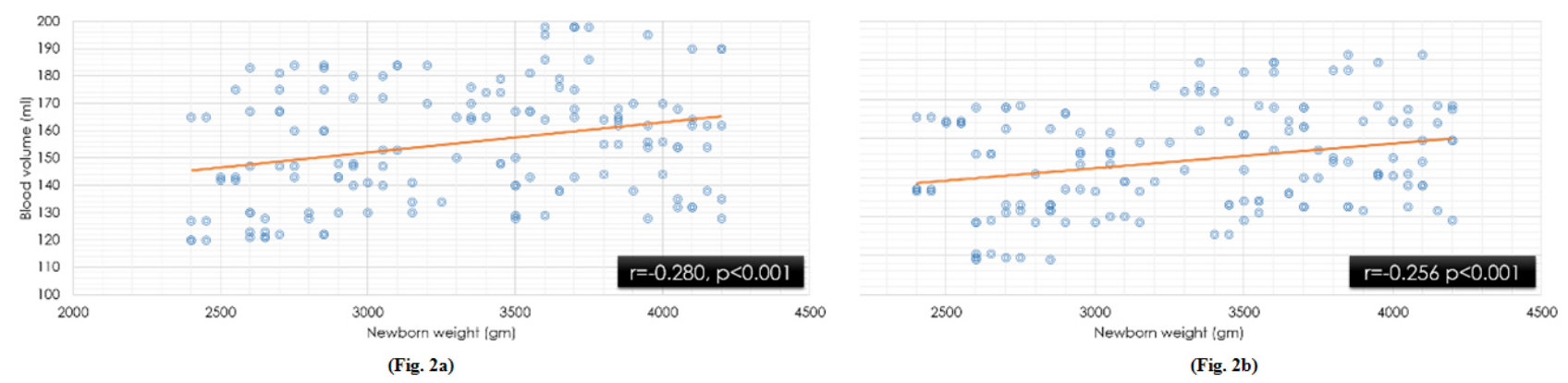

Figure 2. Correlation between the newborn weight and (a) blood volume and (b) TNC content 


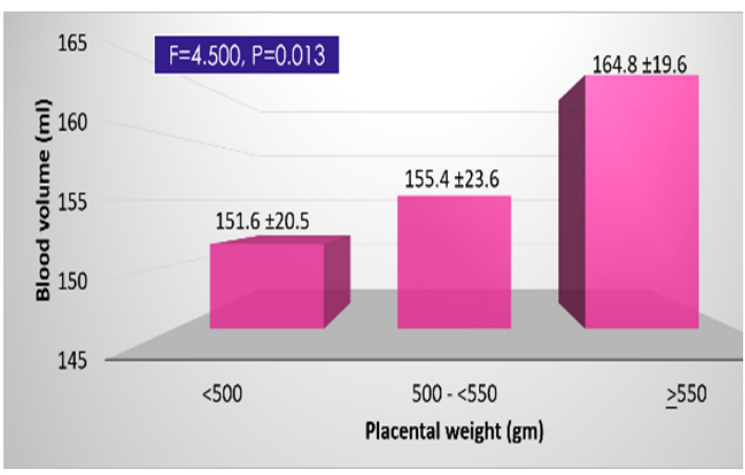

(Fig. 3a)

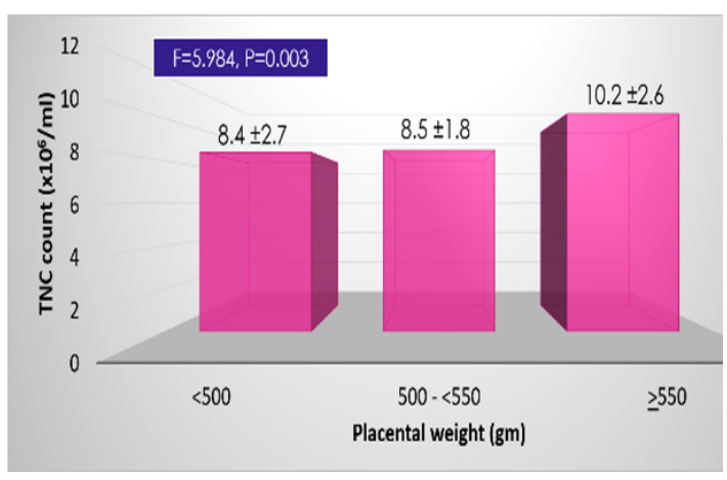

(Fig. 3b)

Figure 3. The association between the placental weight and UCB volume and TNC content

The present study subjects did not included active smokers. But a comparison between the cord blood volume and total nucleated cell content among the participants' exposed to cigarette smoke and those not exposed to cigarette smoke during pregnancy was done. It was evident in the current study that the passive smokers gave a lesser UCB volume and lower total nucleated cell count. Passive smokers are forced to breathe air contaminated by tobacco. This is resulting in increased risk of delivering smaller babies which in turn a predictor for lesser cord blood volume and lower cellular count. ${ }^{[16]}$ Smoking factor was not considered in previous studies, making it difficult to compare the present finding with others.

The prevailing study found no significant difference between both neonatal genders for the given blood volume and nucleated cell count. Two previous reports enforced this finding. ${ }^{[8,15]}$ However, these findings are contradicted with other two studies. ${ }^{[7,17]}$ Female neonates were found to produce larger UCB volume and higher nucleated cell content in a study by Keersmaekers and colleagues, ${ }^{[7]}$ while male neonates were reported to give larger UCB volume in an Egyptian study. ${ }^{[17]}$ Cause of the present study finding is unclear. However, larger blood volume production with higher cell count among male gender can be explained by that the birth weight of males are heavier than that of females ${ }^{[18]}$ and in the current study there was an evidence that with heavier birth weight there was larger blood volume and parallel higher cell count.

Unsurprisingly, the present study results showed a positive relation between the neonatal birth weight and UCB volume and content of the total nucleated cell. Herein, with increased neonatal birth weight from 3,600 $\mathrm{g}$ to above, there were larger blood volume and higher total nucleated cell count. To find the factors that can influence the acceptability of UCB units for banking, Keersmaekers et al., ${ }^{[7]}$ reported that greater birth weight was associated with greater UCB volume and total nucleated cell count and reinforced the present study finding. Congruence with the current study findings and that of Keersmaekers, Brazilian study ${ }^{[19]}$ conducted on 458 UCB units at a public UCB bank in Santa Catarina. The Brazilian study investigated the relation between certain obstetric variables including neonatal weight, and UCB quality indicators. The investigators of such study found that the greater UCB volume and total nucleated cell content were were associated with increasing neonatal weight than $3,500 \mathrm{~g}$. Authors of the present study, attributed the larger blood volume among bigger neonates to the evidence that each $1.98 \mathrm{~g}$ increase in birth weight is related to an increase of $1 \mathrm{gm}$ increase in placenta weight. This increase in placenta weight results in increased vascularity in the placental disc and giving a larger blood volume. ${ }^{[20]}$

In the current study, there were significant differences between the blood volume and nucleated cell content taken from the first baby and those taken from the after coming ones. There were larger blood volume and higher cellular count among the first born babies compared to the second or more babies. Approved with the present study finding, Ballen and colleagues ${ }^{[21]}$ observed a significant association between the birth order and the UCB blood content of total nucleated cell in favor to the first baby. As the first baby had a cell count of $2.6 \times 10^{6}$ cells, second baby $2.4 \times 10^{6}$ cells, third baby $1.9 \times 10^{6}$, and subsequent babies $1.3 \times 10^{6}(p<$ $.001)$. There was a decrease in the UCB volume with each subsequent live birth.

Authors of the present study attributed this finding to two reasons. First reasoning is a notional hypothesis; first babies have the most advantageous values with decreasing advantages in upcoming births. The second reasoning is that the first baby exposed to a longer duration of labor equated to the after coming ones. Longer exposure to uterine contractions was reported to be associated with higher number of 
neonatal nucleated cell count. ${ }^{[22]}$ Conversely, this finding is contradicted with that of a Brazilian study ${ }^{[23]}$ involved 40 UCB units and with Abdelrazek and coauthors findings; ${ }^{[15]}$ stated that order of birth was found to have no impact on the UCB cell count without stating a clear explanation for such findings.

It was observed in the current study that with increased placental weight; over $550 \mathrm{~g}$, there was larger blood volumes and higher total nucleated cell count. Agreed with this finding, Italian study ${ }^{[24]}$ examined the relation of placental weight with the collected UCB volume and its total nucleated cell content in 304 collected UCB units. The Italian study was revealed that with increasing placental weight over $600 \mathrm{~g}$, there was a larger production of blood volume and higher nucleated cell content. ${ }^{[24]}$ This finding may be explained by the notion that with increased placental weight, there is higher fetal blood supply giving greater blood volume and so cellular content. However, Abdelrazek et al., ${ }^{[15]}$ partially agreed with this finding and casts doubt the current study evidence; heavier placenta provides larger blood volume and higher cell count, by demonstrating that placental weight positively associated with the collected blood volume not total nucleated cell count.

\section{Nursing implications}

The need for UCB units is more likely to increase in the near future. It is essential that the staff working at the labour and delivery room share in making guiding principles regarding UCB stem cell collection. This is may be achieved by un- derstanding the factors that improve the amount and cellular content of cord blood. Hence that more units are available for utilization.

\section{CONCLUSION AND RECOMMENDATIONS}

Briefly, UCB units with larger blood volume and higher cellular content could be gained from the first born baby with higher birth weight and heavy placenta belonged to primigravida at earlier gestation; between 37 to 40 weeks, and did not exposed to cigarette smoke during pregnancy. Irrespective to the neonatal gender or the mother's age. These findings incite the following recommendations:

(1) Maternity staff are advised to consider, gravidity number, gestation weeks, exposure of mothers to cigarette smoke, placental weight, and neonatal order of birth and weight in collecting in utero UCB units from neonates born by Cesarean section.

(2) Future research studies exploring the hypothesis "maternal and fetal compromise may positively affect the sufficiency and efficiency of cord blood stem cell"; would be of interest.

\section{ACKNOWLEDGeMENTS}

The researcher is appreciative for the help of the staff members working in the MARK-CSC and in the hematology laboratory of Mansoura University.

\section{CONFLICTS OF INTEREST Disclosure}

The authors declare that there is no conflict of interest.

\section{REFERENCES}

[1] Lie AK, Au WY, Liang R. Haematopoietic stem cell transplantation in Hong Kong. Hong Kong Med J. 2009 Jun; 15(3 Suppl 3): 17-21.

[2] Chan CF, Leung T, Chan LY, et al. Umbilical Cord Blood for Transplantation: from Collection Quality to Its Use in Cerebral Palsy. Hong Kong J Gynaecol Obstet Midwifery. 2009; 9(1): 43-8

[3] Haller MJ, Viener HL, Wasserfall C, et al. Autologous umbilical cord blood infusion for type 1 diabetes. Exp Hematol. 2008 Jun; 36(6): 710-5.

[4] European Group on Ethics in Science and New Technologies: Opinion n. 19. Ethical aspects of umbilical cord blood banking. 16 March 2004. Available from: http://ec.europa.eu/european_grou p_ethics/publications/docs/publop19_en.pdf

[5] Petrini C. Umbilical cord blood banking: from personal donation to international public registries to global bioeconomy. Journal of Blood Medicine. 2014; 5: 87-97. PMid:24971040 https: //doi.org/10.2147/JBM. S64090

[6] Tam MS, Chin RK, Boyd R, et al. The impact of obstetric parameters on haematopoietic stem cells extracted from the umbilical cord blood in the Chinese population. Hong Kong Journal Gynaecology Obstetrics Midwifery. 2014; 14: 82-8.
[7] Keersmaekers CL, Mason BA, Keersmaekers J, et al. Factors affecting umbilical cord blood stem cell suitability for transplantation in an in utero collection program. Transfusion. 2014; 54(3): 545-9. PMid:23869580 https : //doi.org/10.1111/trf . 12340

[8] Al-Qahtani R, Al-Hedythi S, Arab S, et al. Factor predicting total nucleated cell counts in cord blood units. Transfusion. 2016 Sep; 56(9): 2352-4.

[9] Yang H, Loutfy MR, Mayerhofer S, et al. Factors affecting banking quality of umbilical cord blood for transplantation. Transfusion. 2011; 51(2): 286-92.

[10] Rosenau EH, Sugrue MW, Haller M, et al. Characteristics of thawed autologous umbilical cord blood. Transfusion. 2012; 52(10): 2234 42. PMid:22321210 https://doi.org/10.1111/j.1537-2995. $2011.03556 . \mathrm{x}$

[11] Charan J, Biswas T. How to Calculate Sample Size for Different Study Designs in Medical Research? Indian Journal Psychology Medicine. 2013; 35(2): 121-126. PMid:24049221 https://doi.or $\mathrm{g} / 10.4103 / 0253-7176.116232$

[12] Wen SH, Zhao WL, Lin PY, et al. Associations among birth weight, placental weight, gestational period and product quality indicators of umbilical cord blood units. Transfusion Apheresis Science. 2012; 
46(1): 39-45. PMid:22206793 https://doi.org/10.1016/j.tr ansci.2011.10.031

[13] Wu JY, Liao C, Chen JS, et al. Analysis of maternal and neonatal factors associated with hematopoietic reconstruction potential in umbilical cord blood units. Zhongguo Shi Yan Xue Ye Xue Za Zhi. 2010; 18(6): 1535-41.

[14] Atanassova V, Atanassova M, Nikolov A, et al. Influence of obstetric factors on the quality of cord blood units collected for allogeneic transplantation. Akush Ginekol (Sofiia). 2012; 51(2): 11-6.

[15] Abdelrazek AM, El Said MN, Abdel Aziz HM, et al. The impact of fetal and maternal physiologic factors on umbilical cord blood quality as a source of stem cells in Egyptian population. Transfusion. 2015 Dec.; (55): 2882-89.

[16] Wei Z, Kohta S, Taichiro T, et al. Association between Maternal Smoking during Pregnancy and Low Birth weight: Effects by Maternal Age. PLOS ONE.

[17] Bassiouny MR, El-Chennawi F, Mansour AK, et al. Optimal method for collection of umbilical cord blood: an Egyptian trial for a public cord blood bank. Transfusion. 2015; 55: 1263-68. PMid:25565448 https://doi.org/10.1111/trf.12978

[18] Kautzky-Willer A, Harreiter J, Pacini G. Sex and Gender Differences in Risk, Pathophysiology and Complications of Type 2 Diabetes Mellitus. Endocrine Reviews. 2016; 37(3): 278-316. PMid:27159875 https ://doi.org/10.1210/er.2015-1137
[19] Nunes RD, Zandavalli FM. Association between maternal and fetal factors and quality of cord blood as a source of stem cells. Brazilian Journal of Hematology and Hemotherapy. 2015; 37 (1): 38-42. PMid:25638766

[20] Sanin LH, López SR, Olivares ET, et al. Relation between birth weight and placenta weight. Biology of the Neonate. 2001; 80(2): 113-7. PMid:11509810 https ://doi.org/10.1159/000047129

[21] Ballen KK, Wilson M, Wuu J, et al. Bigger is better: maternal and neonatal predictors of hematopoietic potential of umbilical cord blood units. Bone Marrow Transplant. 2001; 27: 7-14. PMid:11244432 https://doi.org/10.1038/sj.bmt.1702729

[22] Donaldson C, Armitage WJ, Laundy V, et al. Impact of obstetric factors on cord blood donation for transplantation. British Journal Hematology. 2001; 106: 128-32. https://doi.org/10.1046/j . 1365-2141.1999.01507.x

[23] Izu M, Silvino ZR, Lima DO, et al. Influence of obstetric and neonatal factors in cellularity and volume of the umbilical cord. Journal Nursing UFPE Line Recife. 2013; 7: 4621-6.

[24] Mancinelli F, Tamburini A, Spagnoli A, et al. Optimizing umbilical cord blood collection: impact of obstetric factors versus quality of cord blood units. Transplantation Proceedings. 2006; 38(4): 1174-76. PMid:16757298 https ://doi.org/10.1016/j.transproceed .2006 .03 .052 